\title{
Et studieår i primærhelsetjenesten - reisebrev fra Australia
}

\section{Australske universiteter tilbyr læringsprogrammer som gir studentene økt interesse for arbeid i distriktene.}

Per Stensland

per.stensland@uib.no

Jeg er på besøk på Flinders University i Adelaide for å studere hvordan legestudiet kan bidra til å sikre leger til distriktene. Flinders er kjent for sin University Rural Clinical School som de etablerte i 1997 og som i dag er fulgt opp av totalt 16 australske universiteter, som alle har egne program for distriktsmedisin. The Rural Clinical School er en «distriktslinje» der studentene tilbringer hele nest siste studieår i et helsesenter utenfor de store byene (1). Undervisningen er praktisk og basert på et mestersvenn-prinsipp. Studentene tar del i klinisk så vel som forebyggende og helsefremmende arbeid i lokalsamfunnet.

\section{Studentene}

Kathleen og Lewis er i ferd med å avslutte studieåret på Kangaroo Island. De forteller at året har vært lærerikt og krevende. Lesingen har vært styrt av hendelsene i praksis. De har til tider tenkt at studentlivet hadde vært enklere med oppsatte kateterforelesninger som sikret gjennomgang av et definert pensum. Den selvstyrte læringen har stilt krav til å skape egen struktur, de har fått et forhold til hva som er relevant stoff og ikke minst har de fått praktisk medisin inn $i$ hendene. Og de har ikke tatt skrekken av erfaringene. Begge vil søke distriktslegejobber før de er ferdige om et år.

\section{Lokalsamfunnet}

Helsesjefen på øya, Nigel Jefford, forteller at rekrutteringen til legestillingene går lettere når de stadig har tilfang fra et miljø av legestudenter som har tidlig praksiserfaring. Han er slått av hvor gode studentene blir i håndtering av praktiske prosedyrer, for eksempel i akuttmedisin. For helsetjenesten på øya er det ellers en styrke at flere av allmennlegene har sideutdanning i fødselshjelp, anestesi og akuttmedisin. Slike delspesialiteter kommer godt med når veien til sykehus er lang.

\section{Veilederen}

Mine kontakter på Flinders har også anbefalt meg å reise nordover, til vindistriktet

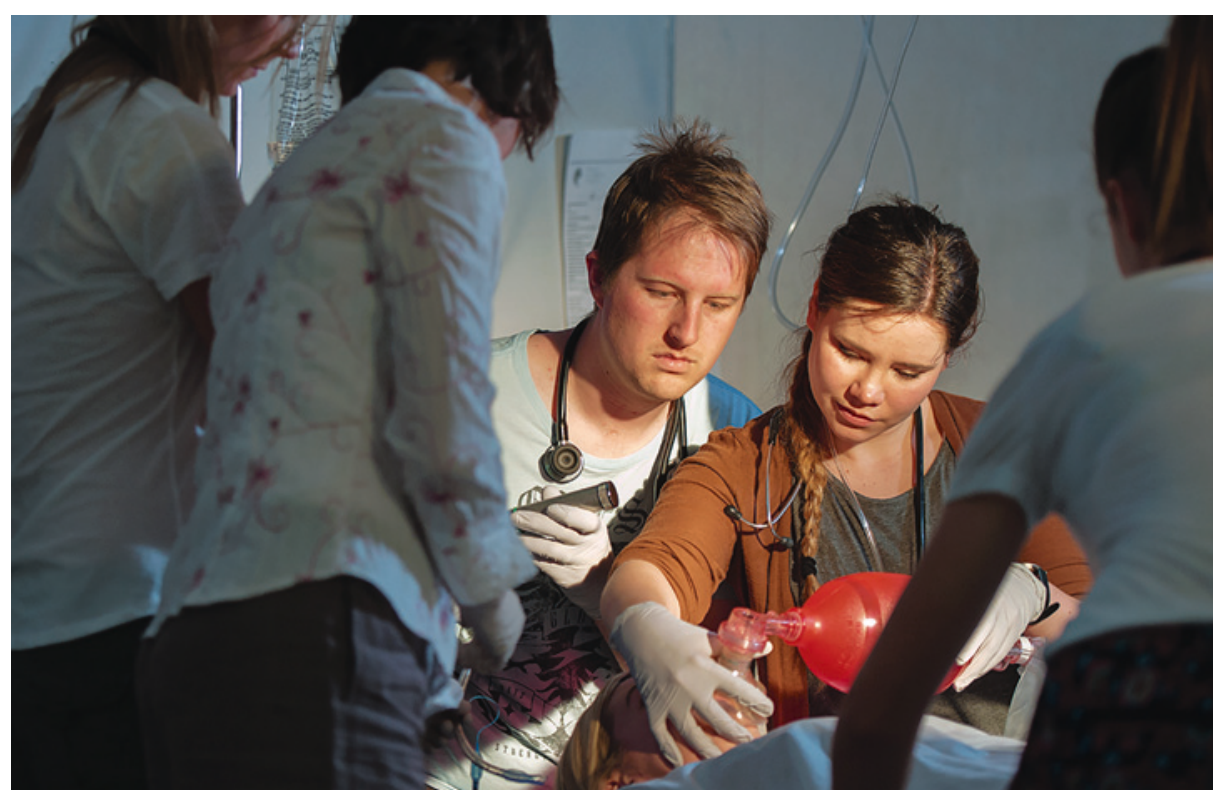

Foto: Flinders University Rural Clinical School

Barossa. Adrian Griscti er studentkoordinator for ti studenter som har praksis i dette området. Han forteller at de har dobbelt så mange søkere til The Rural Clinical School som de kan ta imot. Dels kan det ha sammenheng med at noen av studentene selv kommer fra distriktsområder og søker seg til denne linjen. Men det har også vist seg at studentene på distriktslinjen lærer mye og får gode karaktererer. De lærer seg å prioritere tema i lesningen, de får undervisning og trener effektivt når de jevnlig samles i smågrupper i nærområdet. Adrian legger vekt på at studentene blir ivaretatt sosialt på en liten arbeidsplass. Som mentor er han godt orientert om trivsel og fremdrift i studiene. Studenter som trenger spesiell tilrettelegging kan få dette på en annen måte enn i en større sykehusgruppe.

\section{Lederen}

Professor Jennene Greenhill er i dag leder av The Rural Clinical School. Hun forteller at det ikke er vanskelig å skaffe gode lokale koordinatorer og veiledere til ordningen. Koordinatorene har stilling som universitetslærere, og disse jobbene bidrar til økt trivsel og stabilitet også i de kliniske stillingene.

Universitetet ønsker langtidskontrakt, helst ti år, med lærestedene. Praksisfelleskapet får kompensasjon for å tilby plass og for å gi undervisning. Greenhill mener det er attraktivt å være lærested. Lokalsamfunnene er fornøyd med at ordningen bidrar til økt stabilitet blant leger og at området får undervisningsutstyr og videokommunikasjon (2).

\section{Dekanen}

«Vi må konsentrere oss om studentenes læring og knytte den til praktisk erfaring», sier professor Paul Worley. Worley, som selv har bakgrunn som distriktslege og var drivkraften bak opprettelse av distriktslinjen i 1997 (3). Nå er han dekan for det medisinske fakultetet ved Flinders.

Han er fornøyd med at halvparten av studentene fra studiet i dag går rett ut i distriktspraksis. Ingen andre universiteter har tilsvarende andel uteksaminerte studenter som velger slik.

I 2004 kunne Worley sammen med medarbeidere vise at studentene fra distriktslinjen i gjennomsnitt hadde bedre eksamensresultater enn studentene ved studier med tradisjonell studieplan (4). Han mener at dette utfordrer dogmet om at sykehusene i tredjelinjetjenesten representerer gullstandarden i utdanningen av medisinstudenter. 
Worley forteller at gruppen hans i økende grad er blitt opptatt av hvordan langvarig praksis i studiet bidrar til bedre læringsmiljø og resultater. Prinsippene er å la studentene delta $\mathrm{i}$ behandling av pasienter over tid, la dem bli godt kjent med og lære av pasientenes behandlere og la dem lære klinisk kompetanse på tvers av medisinske spesialiteter.

\section{Mine hovedinntrykk}

Det er fullt mulig å lokalisere et helt år av studiet i primærhelsetjenesten. Kvotering av studenter med distriktsbakgrunn ved studieopptak og langvarig praksis har ført til at halvparten av studentene søker seg til primærhelsetjenesten etter studiet.

Studentene på distriktslinjen har bedre studieresultater enn studenter som har hatt tradisjonell studieplan. Den langvarige lærer-student-relasjonen ivaretar studentene faglig og sosialt og har økt trivselen til lærerne.

\section{Per Stensland (f. 1949)}

er dr.med., fylkeslege i Sogn og Fjordane og professor ved Universitetet i Bergen.

Forfatter har fylt ut ICMJE-skjemaet og oppgir ingen interessekonflikter.

\section{Litteratur}

1. Flinders University. www.flinders.edu.au/ medicine/sites/furcs/ (30.10.2015).

2. Greenhill JA, Walker J, Playford D. Outcomes of Australian rural clinical schools: a decade of success building the rural medical workforce through the education and training continuum. Rural Remote Health 2015; 15: 2991.

3. Worley PS, Prideaux DJ, Strasser RP et al. Why we should teach undergraduate medical students in rural communities. Med J Aust 2000; 172: 615-7.

4. Worley P, Esterman A, Prideaux D. Cohort study of examination performance of undergraduate medical students learning in community settings. BMJ 2004; 328: 207-9

Mottatt 2.11. 2015, første revisjon innsendt 17.11. 2015, godkjent 10.12. 2015. Redaktør: Ketil Slagstad. 